BLOOD-BRAIN BARRIER PERMEABILITY (BBBR) IN "HEALTHY" INFECTED AND STRESSED NEONATES

77 D.Anagnostakis, D.Damianos, E.Touni, H.Mandyla,

lst Dept of Pediatrics, Athens University, Athens Greece

The BBBP was studied in 76 full term neonates tapped for work. up for meningitis and divided in 4 groups according to pertinent clinical and laboratory findings. A. 38"healthy"neonates wi thout sepsis or meningitis and subsequent uneventfull clinical course $B .10$ with bacterial meningitis $C .15$ with asseptic meningitis and D.13 stressed neonates without meningitis but with severe diseases (septicemia,perinata? asphyxia etc).BBBP was assessed by CSF/ serum albumin ratio $\left(\times 10^{3}\right)$ and the results (mean $\left.\pm S D\right)$ are summarized: Group $A$ Group $B$ Group $C$ Group D $8.5( \pm 3.1) \quad 39.7( \pm 17.5) \quad 10.0( \pm 2.7) \quad 26.9( \pm 9.5)$ BBBP in group $B$ was higher than in group $A(p<0.001)$ and $C(p<0.001)$ Group $D$ had a higher BBBP than groups $A(p<0.001)$ and $C(p<0.001)$ These results indicate that a) grounates with asseptic meningitis have a BBBP similar to that of "healthy"ones. b) stressed and neonates with bacterial meningitis have a high BBBP. The above suggest that a)BBBP can differentiate asseptic from bacterial meningitis and b) the high BBBP in stressed neonates should be considered in jaundiced and in neonates receiving drugs.
Effect of indomethacin on cerebral oxidised cytochrome aa concentration in preterm infants.

D.C.McCormick, A.D.Edwards, J.S. Wyatt, A.Potter, M.Cope, D.T.Delpy, E.O.R.Reynolds. Depts of Paediatrics, and Medical Physics and Bioengineering, University College and Middlesex School of Medicine London.

Using near infrared spectroscopy (NIRS) we have shown previously that the intravenous administration of indomethacin for treatment of pitent duchus arteriosus (PDA) in sick preterm infants caused a reduction of approximately $40 \%$ in cerebral oxygen delivery'. We have used NIRS to investigate the effect of this change on the cerebral concentration of oxidised cytochrome $a_{3}\left(\left[\mathrm{CytO}_{2}\right]\right)$, the terminal on the cerebral concentration of oxidised cytochrom

Studies by NIRS were performed on 15 infants bom at 23-29 weeks gestation weighing 600-1620 grams, who required treatment for PDA aged 8-27 days. Infants received indomethacin $0.1-0.2 \mathrm{mg} \cdot \mathrm{kg}^{-1}$, seven by fast ( $\left.30 \mathrm{secs}\right)$ and eight by slow (30 mins) infusion. The expected haemodynamic changes were seen in ail infants. In 5 infants an unequivocal fall in $\left[\mathrm{CytO}_{2}\right]$ was observed (range 0.3-0.9 $\mu$ mol. $\left.1^{1}\right)$, while the remaining 10 infants showed no definite change. No significant difference between the fast and slow infusion was observed.

We conclude that following indomethacin the close relationship between cerebral intracellular oxygen supply and ccrebral energy metabolism was frequently maintained, but in 5 cases there was evidence of a relative intracellular oxygen deficit.

1. AD Edwards et al. Pediatr Res 1989;26:522
THE WHOLE BODY TLRNOVER RATES OF TRNA AND TRNA ARE CORRELATED WITH THE BASAL YETABOLIC RATE IN MAMMALS

\section{OF DIFFERENT SIZE}

G. Schöch", H. Topp, S. Fenselau, O. Jöhren,

E. Fuchs, D. Gädeken. G. Heller-Schöch, G. Sander Forschungsinstitut für Kinderernährung. Dortmund, FRG

We have developed a noninvasive method to determine whole body turnover rates of tRNA, rRNA and mRNA in mamals by measuring specific, quantitatively excreted modified RNA catabolites (nucleosides, nucleobases) in urine by HPLC. An investigation of the turnover rates of rRNA and tRNA in pigs, human adults, preterm infants, sheep, goats, rats, hamsters, wice ranging in mean body weight from $126 \mathrm{~kg}$ (pigs) to $0.028 \mathrm{~kg}$ (mice) reveals that the rRNA and tRNA turnover rates pe: unit body weight correlate with the basal metabolic rates (BMR) per unit body weight (calculated by the formula: BMR $(\mathrm{kJ} \mathrm{x} \mathrm{d}-1)=240 \times \mathrm{kg}$ body weight (calculated by the formula: BMR ( $\mathrm{kJ} \mathrm{x}-1$ ) $=240 \mathrm{xg}$ body species and the rRNA turnover rates is 0.995; that between the BMR of 6 species (mice excluded) and the tRNA turnover rates is 0.998 . We believe that our method for determining the whole body turnover rates of different RNA classes will be useful to assess the metabolic state in mamals. This method could turn out to be useful for early diagnosis and thus for the prevention of metabolic stress (e.g. caused by food deficiency and/or infections) as well as for monitoring therapeutic success.
Response of cerebral blood volume to changes in arterial carbon dioxide tension in newborn infants.

J.S.Wyatt, A.D.Edwards, D.C.McCormick, M.Cope, D.T.Delpy, 81 E.O.R.Reynolds. Depts of Paediatrics, and Medical Physics and Bioengineering, University College and Middlesex School of Medicine. London.

The purpose of this study was to define gestation-related changes in the response of cerebral blood volume to changes in arterial carton dioxide tensio $\left(\mathrm{PaCO}_{2}\right)$. Twelve newbom infants bom at $27-41$ (median 31) weeks of gestation were studied aged 8-97 (26) hours by near infrared spectroscopy (NIRS). All were receiving mechanical ventilation and had normal brains as judged by clinical criteria and ultrasound scans.

NIRS was performed at the cotside and measurements of cerebral blood volume made as previously described ${ }^{1}$. Following baseline measurements $\mathrm{PaCO}_{2}$ was altered by $1-2 \mathrm{kPa}$ in the range $3.9-9.6 \mathrm{kPa}$ by adjusting the ventilator rate. The change in cerebral blood volume in response to changing $\mathrm{PaCO}_{2}$ was calculated for each infant. A highly significant positive linear relation between gestational age and this response was found (ANOVA, $p<0.01$ ) The mean value for the regression at 27 weeks gestation was $0.15(95 \% \mathrm{CI}-0.09,0.39) \mathrm{ml} .100 \mathrm{~g}^{-1} \cdot \mathrm{kPa}^{-1}$ and at 41 weeks 0.58 (95\% CI $0.33,0.83) \mathrm{ml} .100 \mathrm{~g}^{-1} \cdot \mathrm{kPa}^{-1}$.

We conclude that the response of cerebral blood volume to changing $\mathrm{PaCO}_{2}$ is markedly diminisned in preterm compared with term infants.

1. JS Wyatt et al. J Appl Physiol (in press)
Ultrasound detected lesions in very preterm infants with symmetrical and asymmetrical neuromotor impairments at one year.

79 A.L.Stewart, A.D.Edwards, S.C.Roth, J.S.Wyatt, J.Townsend, E.O.R.Reynolds. Department of Pacdiarrics, University College and Middlescx School of Medicine, London.

Epidemiological evidence ${ }^{1}$ suggests that the actiology of symmetrical (Sy) and asymmetrical (Asy) neuromotor impairments may differ. We have investigated 85 infunts bom at less than 33 wecks gestation whose brains were examined using uluasound sector scanning in the neonatal period and then had neuromotor impairments identified at one year. In 38 infants the impairment was Sy, in 27 Asy and in 20 involved only the axis. The infants were part of a consccutive cohor of 362 infants bom in 1983-85; they comprised $90 \%$ of the 94 impaired infants in the cohor. The results were as follows:

$\begin{array}{lccccl} & \mathrm{n} & \begin{array}{l}\text { Abnomal } \\ \text { Scan }\end{array} & \begin{array}{c}\text { Ventricular dilatation } \\ \text { or Hydrocephalus }\end{array} & \begin{array}{c}\text { Parenchymal } \\ \text { Hacmorthage }\end{array} & \text { Cystic } \\ \text { Sy } & 38 & 23(61 \%) & 11(29 \%) & 2(6 \%) & 2(6 \%) \\ \text { Asy } & 27 & 23(85 \%) & 4(15 \%) & 10(37 \%) & 1(4 \%) \\ \text { Axis } & 20 & 19(95 \%) & 11(55 \%) & 0 & 2(10 \%) \\ \text { Total } & 85 & 65(76 \%) & 38(45 \%) & 12(14 \%) & 5(6 \%)\end{array}$

Both the prevalence and the type of uitrasound-detected brain lesions differed amons the three groups of neuromotor impaiments. These findings support the epidemiological evidence of differing actiologies for Sy and Asy impairments.

1. Powell et al. Dev Med Child Neurol 1988:30:11-18,19-25
Relation between arterial carbon dioxide tension and cerebral oxidised cytochrome $\mathrm{aa}_{3}$ concentration in preterm infants. A.D.Edwards, J.S.Wyatt, D.C.McCormick, S.C.Roth, M.Cope, A.Potter, 82 D.T.Delpy, E.O.R.Reynolds. Depts of Paediatrics, and Medical Physics Medicine, London.

The aim of this study was to find out whether the intracerebral concentration of cytochrome $\mathrm{aa}_{3}\left(\left[\mathrm{CytO}_{2}\right]\right.$ ) (the terminal enzyme of the respiratory electron transport chain) altered in response to changes in arterial carton dioxide tension $\left(\mathrm{PaCO}_{2}\right)$

Six infants bom at 23-36 (median 28) weeks of gestation and aged 1-6 (2) days were studied by near infrared spectroscopy as previously described ${ }^{1}$. The infants were mechanically ventilated and had no clinical or ultrasonographic evidence of cerebral injury. $\mathrm{PaCO}_{2}$ was altered by $0.8-1.3(1.1) \mathrm{kPa}$ within the range $4.3-9.6 \mathrm{kPa}$ cerebral injury. $\mathrm{PaCO}_{2}$ was altered by $0.8-1.3(1.1) \mathrm{kPa}$ within the range $4.3-9.6 \mathrm{kPa}$
by changes in ventilator rate, and the effect on total cerebral haemoglobin concentration $([\mathrm{tHb}])$ and $\left[\mathrm{CytO}_{2}\right]$ observed. In all infants these variables were positively related: The change in $\left[\mathrm{CytO}_{2}\right]$ with changes in $\mathrm{PaCO}_{2}$ ranged from 0.10 to $0.40(0.25) \mu \mathrm{mol}_{1} \mathrm{l}^{-1} . \mathrm{kPa}^{-1}$. The ratio $\Delta\left[\mathrm{CytO}_{2} y \Delta[\mathrm{tHb}]\right.$ ranged from 0.063 to 0.119 $(0.083)$. There was no positive relation between changes in $\left[\mathrm{CytO}_{2}\right]$ and arterial oxygen saturation $\left(\mathrm{SaO}_{2}\right)$, which ranged from 88 to $98 \%$.

We conclude that $\left[\mathrm{CytO}_{2}\right]$ was directly related to $\mathrm{PaCO}_{2}$, probably through changes in cerebral perfusion. However $\left[\mathrm{CytO}_{2}\right]$ did not appear to be related to $\mathrm{SaO}_{2}$ in the range studied.

1. IS Wyatt et al. Arch Dis Child 1989;64:953-967 